Fhumulani Tshidavhu

Ms Fhumulani Tshidavhu, Old Mutual Building, 78 Hans Van Rensburg Street, Polokwane, 0699, Limpopo, RSA National Department of Public Works, Polokwane, South Africa. Phone: 071679 8604, e-mail: <Fhumulani.Tshidavhu@dpw. gov.za>

\section{Nthatisi Khatleli}

Dr Nthatisi Khatleli, senior lecturer, School of Construction Economics and Management, University of the Witwatersrand, Johannesburg, South Africa.

Phone: 0117177651 ,

e-mail: <Nthatisi.Khatleli@wits.ac.za>

DOI: http://dx.doi.

org/10.18820/24150487/as27i1.5

ISSN: 1023-0564

e-ISSN: 2415-0487

Acta Structilia 2020 27(1): 119-143

OPEN ACCESS

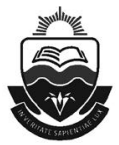

Published by the UFS

http://journals.ufs.ac.za/index.php/as

(c) Creative Commons With Attribution (CC-BY)

How to cite: Tshidavhu, F. \& Khatleli, N. 2020. An assessment of the causes of schedule and cost overruns in South African megaprojects: A case of the critical energy sector projects of Medupi and Kusile. Acta Structilia, 26(2), pp. 119-143.

Peer reviewed and revised March 2020

Published June 2020

*The authors declared no conflict of interest for the article or title

\begin{abstract}
Cost and schedule overruns are the most common challenges in mega construction projects around the globe, and South Africa is no different. Although comparatively small in number, megaprojects have an inordinate number of projects failing, due to budget overflow and schedule slippage. This article assessed the causes of cost and schedule overruns as well as the challenges with the implementation of critical construction megaprojects, using Kusile and Medupi energy-sector megaprojects in South Africa. Using a quantitative research method, which included a literature review and a questionnaire survey, identified the causes of schedule and cost overruns as well as the challenges militating against the project's implementation success. Data was collected from engineers, quantity surveyors, architects, contractors, and project managers who were randomly selected from the two megaprojects, Medupi and Kusile. Data was analysed using mean score ratings and ranking. The results revealed that slow client decision-making, shortages of skilled
\end{abstract}


labour, inaccurate material estimating, unforeseen ground conditions, poor material planning, changes in scope of work on-site, contractual claims, variation orders and poor site management were the major causes of schedule and cost overruns. Findings show that the top five challenges (poor site management, inadequate managerial skills, poor monitoring and control, unstable management structure, and lack of experience together with poor organisation structures) is all management and organisational related, showing that there is not enough local management and organisational expertise in South Africa to ensure the proper planning and effective implementation of energy megaprojects. This article is relevant, as it contributes to the understanding of key challenges faced by megaprojects in the context of a developing country. Specific solutions that mitigate the causes of schedule and cost overruns should be investigated in future studies.

Keywords: Cost overruns, energy sector, megaprojects, schedule overruns

\section{ABSTRAK}

Oorskryding van koste en skedules is die mees algemene uitdagings in megakonstruksieprojekte regoor die wêreld, en Suid-Afrika is nie anders nie. Alhoewel dit relatief klein is, het megaprojekte 'n buitengewone aantal projekte wat misluk as gevolg van oorloop van die begroting en glyplanne. Hierdie artikel het die oorsake van koste- en skedule-oorskrywings, sowel as die uitdagings met die implementering van megaprojekte vir kritiese konstruksie, met behulp van megaprojekte vir die energiesektor (Kusile en Medupi) in Suid-Afrika, ondersoek. Deur gebruik te maak van 'n kwantitatiewe navorsingsmetode, wat 'n literatuuroorsig en 'n vraelysopname insluit, is die oorsake van skedule- en koste-oorskrydings, asook die uitdagings met megaprojekimplementering, geïdentifiseer. Data is versamel van ingenieurs, bourekenaars, argitekte, kontrakteurs en projekbestuurders wat lukraak gekies is uit die twee megaprojekte, Medupi en Kusile. Data is geanaliseer met behulp van gemiddelde telling graderings en posisie. Die resultate toon dat trae kliëntbesluitneming, tekort aan geskoolde arbeid, onakkurate materiaalberaming, onvoorsiene grondtoestande, swak materiaalbeplanning, veranderinge in werkomvang op die terrein, kontraktuele eise, afwykingsbevele en swak terreinbestuur die belangrikste oorsake van die skedule- en koste-oorskryding was. Resultate toon dat die top vyf uitdagings (swak terreinbestuur, onvoldoende bestuursvaardighede, swak monitering en beheer, onstabiele bestuurstruktuur en gebrek aan ervaring tesame met swak organisasiestrukture) alles bestuurs- en organisatories verwant is. Dit toon dat daar nie genoeg plaaslike bestuursen organisasiekundigheid in Suid-Afrika is om die behoorlike beplanning en effektiewe implementering van energie-megaprojekte te verseker nie. Hierdie artikel is relevant, aangesien dit bydra tot die begrip van die belangrikste uitdagings wat megaprojekte in die konteks van 'n ontwikkelende land in die gesig staar. In toekomstige studies moet spesifieke oplossings ondersoek word om die oorsake van skedule- en kosteoorskrydings te verlig.

Sleutelwoorde: Koste-oorskryding, energiesektor, megaprojekte, skedule-oorskryding

\section{INTRODUCTION}

A megaproject is defined as a project that costs $\$ 1$ billion or more (Flyvbjerg, 2014: 3). Megaprojects are expensive, and include many risk factors that can cause delays or failures during the project's execution (Ma, Zeng, Lin, Chen \& Shi, 2017: 1). In practice, cost and schedule overruns are generally an ongoing problem in megaprojects implementation in the vast majority of sectors (Aljohani, Ahiaga-Dagbui \& Moore, 2017: 137; Famiyeh, 
Amoatey, Adaku \& Agbenohevi, 2017: 182). The Sydney Opera House is an example of a megaproject that was overbudget and completed well outside of the proposed schedule; it was ten years overschedule, and its construction cost was $1400 \%$ overbudget (Flyvbjerg, 2014: 9). In the transportation sector, for instance, Flyvbjerg, Bruzelius and Rothengatter (2003: 1) conducted the largest and most encompassing study of cost overruns on a sample of 258 major roads, tunnels, bridges, urban transit, and interurban rail projects in 20 countries on five continents. The study concluded that nine out of ten megaprojects experienced cost overruns (Siemiatycki, 2015: 2).

In South Africa, large-scale projects are required by law to address both pro-growth and pro-poor socio-economic development goals (Sutherland, Sim \& Scott, 2015: 185). Large-scale infrastructure projects in South Africa are promoted as having the possibility to drive economic growth, create employment opportunities, and ensure that benefits percolate to the poor and economically marginalised (Sutherland et al., 2015: 186). However, insisting on using megaprojects as a driver of economic growth and a means of social redistribution is challenging, as literature abundantly reveals their failure in addressing social concerns (Dupont, 2013: 3).

There are a few megaprojects in progress or recently completed in SouthAfrica in the energy and transport sectors, namely Medupi Power Station (Eskom), Kusile Power Station (Eskom), the New Multi-Product Pipeline (Transnet), and the Durban port upgrade and expansion project (Transnet). Medupi Power Station is a dry-cooled, coal-fired power station that is being built near Lephalale in Limpopo province. It is the fourth dry-cooled, baseload station to be built in 20 years by Eskom after Kendal, Majuba, and Matimba power stations (Phaahla, 2015: 2). Medupi and Kusile power stations have both suffered delays in construction. Medupi was initially planned to be completed in four years and is currently in its seventh year of construction, and was expected to be completed in 2019 (Phaahla, 2015: 2). The Kusile Power Station project, which is located near the existing Kendal Power Station, in the Nkangala district of Mpumalanga, will comprise six units, each rated at $800 \mathrm{MW}$ installed capacity for a total capacity of $4800 \mathrm{MW}$. Once completed, Kusile will be the fourth-largest coal-fired power station in the world (Eskom, 2019: 1). Kusile started in 2008 and was expected to be completed by the end of 2014; however, the project is still not completed. The original cost was estimated at R69.1 billion; by July 2016, the cost to completion (CTC) was placed at R160 billion (Yelland, 2019: 1).

The New Multi-Product Pipeline is South Africa's largest pipeline project. It is designed to transport liquid fuel from Durban to Johannesburg. The pipeline system will transport five grades of refined fuel, and will provide three pump stations and delivery depots along the route as well as a coastal and inland fuel terminals. This new facility will provide the 
capacity to meet the forecasted fuel needs of the inland market for the year 2030 (ARUP, 2012: 1). The initial cost was R12.7 billion; this amount later increased to R15.4 billion and it further escalated to R23.4 billion in 2012. However, the state-owned entity has stated that R30.4 billion was ultimately invested in the pipeline project. The new multi-pipeline project has been dogged by delays and cost overruns, but it will significantly improve the security of supply risk for Gauteng's fuel supply (Groenewald, 2017: 1).

There is also the Durban port upgrade and expansion project. Durban is the biggest and busiest port in South Africa, and the busiest in the southern hemisphere. It currently handles $64 \%$ of the country's seaborne container traffic. Transnet is implementing this project to increase the Durban container terminal handling capacity (Barradas, 2017: 2). Transnet stated that its contractor has unfortunately terminated this R4.2 billion contract, which was meant to create deeper berths at the Durban container terminal (Barradas, 2019: 1).

To understand the influence of cost and schedule overruns in megaproject construction, it is important to identify and assess the challenges militating against megaprojects success in South Africa. The bias will be towards energy projects, as they are the biggest in value and have received the largest publicity and media scrutiny because of their importance to the functioning of the economy. This article, therefore, assessed the causes of schedule and cost overruns as well as the challenges experienced with the implementation of critical construction megaprojects, using the Kusile and Medupi energy sector in South Africa.

\section{LITERATURE REVIEW}

\subsection{Cost and schedule overruns}

Cost is the budgeted expenditure that the client has agreed to commit to the execution of the project (Subramani, Sruthi \& Kavitha, 2014: 3). Cost overrun is defined as the difference between the actual and the estimated cost (Subramani et al., 2014: 3). According to Vidalis and Najafi (2002: 2388), cost overrun is a "percentage difference between the completion cost and the contract bid cost" (Shrestha, Burns \& Shields, 2013: 2).

Time overrun is defined as the difference between the construction bid duration and the completion duration (Shrestha et al., 2013: 2). Mukuka, Aigbavboa and Thwala (2015: 1691) describe schedule overrun as the extra time required to complete a given project beyond its original planned duration, whether compensated for or not. Cost and schedule overruns is more pertinent when the failure affects the entire economy, such as in the implementation of energy projects that are critical in averting widespread load-shedding. 


\subsection{Causes and implications of megaproject delays and cost overruns}

Approximately only $20 \%$ of megaprojects in Africa reach financial closure and can move to execution, due to cost and schedule overruns during construction (Adugna, 2015: 11; Deloitte, 2014: 3).

Schedule overrun for megaprojects affects all project stakeholders such as clients, contractors, engineers, regulators, and politicians, and is critical to both the contractor and project owner in terms of money and performance, respectively (Subramani et al., 2014: 1; Alaghbari, Kadir, Salim \& Ernawati, 2007: 193). The causes of schedule overruns can be related to the contractor, the consultant, the client, and/or other external factors that occur prior to and during the construction phase (Mukuka et al., 2015: 1691). Schedule overrun becomes a liability for contractors when the completion period becomes longer, raw materials may get more costly, due to inflation, and labour costs can increase (Subramani et al., 2014: 2). In South African energy megaprojects, the client is essentially the government through its agency (parastatal) Eskom.

There is a perception that large projects will produce economies of scale; therefore, most of the megaprojects are financed by national governments and private capital development banks (Callegari, Szklo \& Schaeffer, 2018: 211). Endemic cost overruns of megaprojects invested in, could, as a result, decrease the investment appeal of these megaprojects (Flyvbjerg, 2014: 5) and the suboptimal use of taxpayers' money (Shrestha et al., 2013: 1).

Project environment challenges, due to weather attributes such as severe wind, precipitation, floods, or hail, can delay the project, due to reduced visibility to move equipment, delays in the delivery of materials, reduced access to the site for workers, damaged infrastructure, and the loss of electrical power (Akanni, Oke \& Akpomiemie, 2014: 92). Political instability can derail a project (Akanni et al., 2014: 92).

Research conducted in Hong Kong identified that causes of delay in construction projects include poor site administration and management; unanticipated ground conditions; slow decision-making by all project teams; employer-initiated variations; essential variation of works; the non-existence of effective communication, and possible preconceptions (Adugna, 2015: 25).

In Malaysia, the main causes of cost overruns and delays in building construction projects are poor scheduling and control of time; delays in the preparation of design documents; ineffective communication between stakeholders; changes in laws and regulations; low labour productivity; lack of knowledge in executing methods (Tahir, Haron, Alias \& Diugwu, 2017: 1); contractor's financial problems that result in the shortage of construction 
materials on-site; owner's financial problems and slowness in decisionmaking; consultant's poor supervision and delays in issuing instructions, and external factors such as materials shortage and poor site condition (Musa, 2012: 5).

Studies in South Africa on the causes of delays in construction projects, not necessarily megaprojects, include delays such as approval of shop drawings; delays in contractors' payments; design changes; conflicts in the subcontractors' work schedule; slow decision-making; design errors; labour shortage; insufficient labour skills; owner intrusion; inadequate contractor expertise; financing and payments problems; labour efficiency; improper planning, and subcontractors' inefficiency (Musa, 2012: 5). Factors that influence cost overruns in public sector projects include change in scope of work on-site; incomplete design on tender stage; extension of time with cost; lack of cost plan and monitoring of funds; delays in pricing variation orders; changes in the scope (Ramabodu \& Verster, 2013: 50); management style; lack of reviews of design; inadequate motivation of workers; economic policies; lack of adequate planning; lack of speedy payment to contractors, and quality of management during design and construction (Olatunji, 2010:5)

Some of the reasons that contribute to cost and schedule overruns in any project (also megaprojects) include design error; inadequate scope; the weather; project changes, and underestimating the time for completing a project (Shrestha et al., 2013: 1). Megaprojects could pose even more causes, given their complexities and the huge conglomeration of activities that are under normal circumstances not linked to one another.

\subsection{The energy megaprojects}

A tremendous increase in energy demand is expected, as there are still roughly 1.2 billion people who do not have modern energy services, in regions such as Asia, Latin America, and parts of Africa (Gray, 2017: 2).

Energy projects can be categorised into nuclear, wind, coal, and biomass (Globe Newswire, 2019: 1). Currently, the world power-generation projects pipeline is worth US $\$ 4.46$ trillion. Asia-Pacific is currently leading, with a project pipeline (including all projects from announcement to execution stage) valued at US $\$ 1.99$ trillion, followed from a distance by the Middle East and Africa with a project value of US $\$ 960$ billion. The Americas have power-generation projects with a value of US $\$ 852.3$ billion, while the pipeline for Europe is valued at US\$739.5 billion; these projects will provide an additional $2450 \mathrm{GW}$ of power capacity globally (Globe Newswire, 2019: 1). Global consumption of energy in 2017 reached 13511 million tonnes of oil equivalent (Mtoe), according to the BP Statistical Review. Asia-Pacific contributed the most at 5744 Mtoe, followed by the Americas with 3473 
Mtoe; Europe and Eurasia with 2948 Mtoe, and the Middle East and Africa with 1347 Mtoe (Globe Newswire, 2019: 1).

Concerning world electricity production, coal continues to have the largest share at $38 \%$, followed by renewables (principally hydropower) at $20 \%$, nuclear at $17 \%$, natural gas at $16 \%$, and oil at $9 \%$. Electricity production is expected to almost double by 2020 (Sims et al., 2003: 263). Over the next 20 years, an unprecedented level of investment in energy infrastructure is predicted. The capital investment required to keep pace with the world's energy needs to the year 2035 has been estimated as $\$ 48$ trillion: $\$ 40$ trillion of this sum will relate directly to investments in new and replacement energy infrastructure (IEA, 2014: 11). It is predicted that Europe alone will invest over $\$ 3$ trillion in the energy sector over this period, and the vast majority $(69 \%)$ of this will be in new power plants (IEA, 2014: 13). Increasing energy demand fosters the development of energy infrastructures (power plants, electrical grid, pipelines, and energy storage). Part of this energy demand will be satisfied by 'small-scale projects' (for example, gas turbine or rooftop photovoltaic plants), but some will be satisfied by large-scale and complex 'megaprojects', due to their capital nature; these include long pipelines, nuclear power plants, large wind farms, and large dams. With the new power plants, there are indications that three quarters of the spending will be on plants using nuclear power and renewable resources, with the remainder of the projects being fossil-fuel power plants (IEA, 2014: 13).

Energy investment decisions are generally guided by government policy rather than by market signals (Locatelli, Palerma \& Mancini, 2015: 21). Government interventions in the installations of new plants represent a highly effective tool of any government's policy and may contribute, as it does on many occasions, to a significant level of public expenditure (Maïzi \& Assoumou, 2014: 850). Power Plant Megaprojects (PPMs) are often implemented too late, are very costly, and usually fail the general populace by not providing the expected benefits (Brookes \& Locatelli, 2015: 3).

\subsection{Importance and implementation of energy megaprojects}

Critical infrastructure is the body of systems, networks, and assets that are so essential that their continued operation is required to ensure the security of a given nation, its economy, and the public's health and/or safety (CISA, 2019: 4). A healthy critical infrastructure is the backbone of modern society, and is essential to national prosperity, because it enhances a nation's productivity, quality of life, and economic progression, by driving growth, creating jobs, and improving productivity, quality of life, and efficiency (Department of Homeland Security, 2019: 1). This underpins growth by enabling the supportive networks upon which the economy 
relies (Critical5, 2015: 2). Therefore, national frameworks and policies must contribute to a clearly articulated message that communicates the value, meaning, and importance of critical infrastructure. Resilient and secure infrastructure is vital for economic prosperity, because it underpins not only the effective operation of businesses and services, but also long-term confidence and planning in a region, and thus ongoing investment levels. Resilient infrastructure should have the ability to withstand and quickly recover from disruptions, deliberate attacks, accidents, or naturally occurring threats or incidents, and must essentially demonstrate robustness, agility, and adaptability (CISA, 2019: 11). Resilient and dependable networks enable business confidence, which leads to increased business investment and growth, and the creation of new economic opportunities (Critical5, 2015: 3).

Disruptions of critical infrastructure have tangible and measurable direct and indirect economic impacts not only on dispersed workforce, commerce and manufacturing sectors, transportation, supply chains, and society as a whole, but also on broader regional and national impacts that can be measured in the loss of business and tax revenue generated in the affected areas (Critical5, 2015: 5).

According to Söderlund, Sankaran and Biesenthal (2018: 9), there are four essential and critical issues in megaproject management: their existence and prevalence; how they are managed and organised; their performance, or, as is generally believed, under-performance, and the future of megaprojects and how they could be enhanced to address major societal challenges. The management of infrastructure investments with high benefit-cost ratios may have a significant impact on government economic objectives and can result in improved confidence in current and future infrastructure (Critical5, 2015; CISA, 2019: 6). New critical infrastructure implementation such as energy projects is essentially critical, because either one has it or one does not have it, but its absence could hit the economy to a screeching halt.

South Africa is an example of the mismanagement of new energy-sector megaprojects. In 2007, the South African economy was healthy when power shortages happened, halting operations at mines and smelters overnight. The then president Thabo Mbeki admitted to the prevarication by the government in not adding generation capacity on time, although there were clear prior signs that the supply was under strain. The power utility had no choice soon after that than to unleash a spending spree. The botched and hurried implementation has haunted the country ever since (Burkhardt \& Cohen, 2019: 1). Corruption and state capture are regarded as the major reasons why coal plants Medupi and Kusile are not delivering electricity as planned and why South Africa is facing crippling blackouts. Medupi and Kusile, the third- and fourth-largest coal power plants globally, were originally scheduled to be completed in 2014 and 2012, respectively, giving 
the country an extra $9600 \mathrm{MW}$ of power, enough to avoid the now incessant blackouts (Gosling, 2019: 1).

It is thus necessary to understand the problems with the implementation of the new critical infrastructure projects, when they are in strategic sectors such as energy.

\subsection{The imperativeness of megaprojects in South Africa's economic survival}

As a direct result of apartheid policies, South Africa's Nationalist government created a unique internal colonial system (Wolpe, 1975: 105), thus creating two parallel economies based on race. By the early 1990s, 'White South Africa' had all the makings of an advanced capitalist economy resplendent with multinational corporations, a sophisticated financial sector, and a functioning welfare system. Across the colour line existed a 'non-White South Africa', largely barred from the formal economy, except as a cheap source of labour, and exhibiting features of an internal colony (Padayachee, 2013: 14).

Megaprojects have become indispensable to easing the developmental bottlenecks occasioned by skewed apartheid societal priorities. These behemothic schemes have been operationalised for socio-economic transformation in sectors ranging from energy and extractives to manufacturing and housing. The 'big project mentality' currently adopted by the government seeks to "solve a whole bunch of problems" through the megaproject framework (Ballard \& Rubin, 2017: 12). South Africa's contemporary megaprojects are being implemented amid a global project-building boom. Gargantuan projects and programmes are increasingly becoming a popular delivery model in many sectors worldwide (Flyvbjerg, 2014: 3). Siemiatycki (2017: 5) posits that megaprojects come in cycles, driven by a convergence of economics, technical advancements, political/economic ideologies, and special interest groups.

Post-1994 South Africa has largely embraced the megaproject framework, with billions of dollars financing huge projects such as the 2010 World Cup stadiums, the world's third- and fourth-largest coal power plants (Medupi and Kusile), the Coega industrial zone, the large-scale 'catalytic projects' delivery strategy in housing, and extensions to ports, roads, and airports (including Cape Town, OR Tambo in Johannesburg, and King Shaka Airport in Durban), among others (Harrison \& Todes, 2017: 2). Politicians have hailed megaprojects as drivers of socio-economic change, despite scant evidence to support these claims. However, it must be acknowledged that the methods of achieving the intended economic growth within a statist context are intertwined with the state's capacity and infrastructural power. Moreover, megaprojects' complexities and long timetables allow for periodic 
renegotiations and, what Gualini and Majoor (2007: 315) term, "frame realignment", or the reframing of project objectives when problems arise. As such, they can be a useful tool for building legitimacy and reinforcing the power of the state, particularly in difficult circumstances. However, the implementers still have to know the common problems and how to solve them. It is thus imperative to collate these problems, using current or past projects, as South Africa does not have a very long history of megaprojects implementation, especially in the energy sector in recent times.

\section{STUDY AREA}

Megaprojects in the context of developing African countries such as South Africa are a new phenomenon; any contextual nuances have to be understood first, then collated, whereafter solutions can be sought. There are not many megaprojects in South Africa, and only two could be studied in the energy sector, since they are the only ones that qualify as megaprojects ( $\$ 1$ billion and above).

\subsection{Medupi power station}

Medupi is a Greenfield coal-fired power plant project located in Lephalale, in the province of Limpopo, South Africa. It is the first dry-cooled baseload station built in 20 years by Eskom, following Kendal, Majuba, and Matimba power stations. The name 'Medupi' is a Sepedi (Northern Sotho language) word meaning "rain that soaks parched lands, giving economic relief". The power station will be the third-largest coal plant in the southern hemisphere and the biggest dry-cooled power station in the world. The boiler and turbine contracts for Medupi are the largest contracts that Eskom has ever signed in its 90-year history (Eskom, 2014: 1). The planned operational life of the station is 50 years. The new power station will comprise six units with a gross nominal capacity of $800 \mathrm{MW}$ each, resulting in a total capacity of $4800 \mathrm{MW}$. Construction activities commenced in May 2007 with the official original price tag of $\mathrm{R} 79$ billion, with the first of the six units of the power plant planned for first power by the end of 2014. This was not met, and in 2020, the project has not completely been commissioned. The cost has since escalated to roughly R143 billion (some sources say R300 billion) (Mail and Guardian, 2019). The final figures are still disputed, though, as will be explained below. On the positive side, job creation was expected to peak at 17000 direct jobs created during construction. The town of Lephalale's gross domestic product (GDP) has increased by approximately $95 \%$ per year as a result of the project's construction activities. The power station will directly grow South Africa's GDP by approximately $0.35 \%$ per year. On a daily basis, 22340 meals were prepared and served to ensure that labourers were well fed to keep the morale and efficiency up (Eskom, 2014: 2). 


\subsection{Kusile power station}

The Kusile power station project, located near the existing Kendal power station, in the Nkangala district of Mpumalanga, will comprise six units, each rated at an $800 \mathrm{MW}$ installed capacity for a total capacity of $4800 \mathrm{MW}$. Once completed, Kusile will be the fourth-largest coal-fired power station in the world. The flue gas desulphurisation (FGD) plant is an integrated chemical plant using limestone as feedstock and producing gypsum as a by-product. The plant will peculiarly use an air-cooling system to help conserve water. The operational life of the power station is expected to be 50 years (Eskom, 2014: 1). Eleven years after construction started, not one of its six $800 \mathrm{MW}$ generator units was delivering power into the grid. Construction started at Kusile in 2008, and all six generation units were planned to be in commercial service by the end of 2014. However, the sad reality facing the country is that, as of July 2019, five years after 2014, only Unit 1 at Kusile had been handed over for commercial service. On the other hand, Units 2 and 3 had been synchronised to the grid; they were still undergoing mandatory testing and commissioning, meaning that the units were not in commercial service by the end of 2019 (Yelland, 2019: 1). The original cost in 2007 was estimated at R69.1 billion; by July 2016, the CTC was placed at R160 billion. However, according to Chris Yelland (Mybroadband, 2019: 1), an energy analyst in South Africa, the figures hide much information, and the real costs are shown in Table 1.

Table 1: True costs of Medupi and Kusile power stations

\begin{tabular}{|l|l|l|}
\hline \multirow{2}{*}{ Costs of the project } & \multicolumn{2}{|l|}{ Cost to complete (CTC) } \\
\cline { 2 - 3 } & Medupi & Kusile \\
\hline Approved CTC, excluding IPC and FGD & R145 billion & R161 billion \\
\hline $\begin{array}{l}\text { Estimated cost of flue gas desulphurisation } \\
\text { (FGD) plant }\end{array}$ & R39 billion & R65 billion \\
\hline $\begin{array}{l}\text { Capitalised interest during construction } \\
\text { (IDC) }\end{array}$ & R50 billion & R226 billion \\
\hline Total cost & R234 billion & R460 billion \\
\hline
\end{tabular}

Source: Mybroadband (2019: 1)

\section{METHODOLOGY}

The purpose of this study was to assess the causes of cost and schedule overruns in South African critical construction megaprojects, using Medupi and Kusile energy sector megaprojects. A quantitative research design was used, in which structured questionnaire surveys enable researchers to generalise their findings from a sampled population (Trueman, 2019; Creswell, 2014). The questionnaire rated the causes of cost and schedule overruns in construction megaprojects as well as the challenges when implementing energy megaprojects. A quantitative research approach 
supports the use of interval Likert-type scales to measure data (Netemeyer, Bearden \& Sharma, 2003) and allows for the use of descriptive statistics to analyse data (Brown, 2015: 11). Several data-analysis strategies are available, but, for this study, the mean scores of interval data were used to calculate the central tendency and to determine the composite (average) score of the Likert-type scale constructs (Bishop \& Herron, 2015: 279).

\subsection{Sampling method and response rate}

The population for this study consisted of 150 built environment professionals identified who are involved in the Kusile and Medupi megaprojects (Cox, 2011; Burns \& Grove, 1993). The identified professionals included 50 engineers, 40 architects, 35 quantity surveyors, ten project managers, and 15 contractors. Since there are many activities at these projects, only respondents who were directly involved with the actual building of the power plants were regarded as the target population. Seventy-five were directly involved with power-plant installation and were the target population, while the others were involved with the associated infrastructure. A sample size of 51 built environment professionals and contractors within the Kusile (25) and Medupi (26) megaprojects were randomly selected to participate in the survey (Alvi, 2016: 35). It was not possible to survey everyone, as some were simply not available. The built environment professionals included 20 engineers, 12 architects, 11 quantity surveyors, four project managers, and four contractors. Although the sample size is not valid and not within the recommended sample size of 108 for a population equal to or above 150 (Krejcie \& Morgan, 1970: 608), the professionals directly involved with the actual building of the power plants chosen substantiate the size of the sample. After several reminders, only 17 - Kusile (seven) and Medupi (ten) - responses were received from the 51 respondents to whom the questionnaires were distributed. According to Moyo and Crafford (2010), contemporary built environment survey response rates range from $7 \%$ to $40 \% ; 33 \%$ is thus acceptable for this study (see Table 2 ).

Table 2: Questionnaire distribution and responses

\begin{tabular}{|l|l|c|c|c|c|}
\hline \multirow{5}{*}{ Description } & Discipline & $\begin{array}{l}\text { Number } \\
\text { distributed }\end{array}$ & $\begin{array}{l}\text { Number of } \\
\text { respondents }\end{array}$ & $\begin{array}{l}\text { \% Responses } \\
\text { received }\end{array}$ & $\begin{array}{l}\text { \% Responses } \\
\text { from total }\end{array}$ \\
\hline \multirow{5}{*}{ Consultants } & Architects & 12 & 5 & $42 \%$ & $29 \%$ \\
\cline { 2 - 7 } & $\begin{array}{l}\text { Quantity } \\
\text { surveyors }\end{array}$ & 11 & 3 & $27 \%$ & $18 \%$ \\
\cline { 2 - 7 } & Engineers & 20 & 5 & $25 \%$ & $29 \%$ \\
\cline { 2 - 7 } & $\begin{array}{l}\text { Project } \\
\text { managers }\end{array}$ & 4 & 4 & $100 \%$ & $24 \%$ \\
\cline { 2 - 7 } & Contractors & 4 & 0 & $0 \%$ & 0 \\
\hline Total & & 51 & 17 & $33 \%$ & $100 \%$ \\
\hline
\end{tabular}




\subsection{Data collection}

During April 2018, an online structured (partly open-ended) questionnaire survey was distributed via email to built environment professionals involved in the Kusile and Medupi megaprojects in South Africa. The questionnaire consisted of four sections. The first section relates to the demographics of the respondents. Section two is a set of nine 7-point Likert-scale items relating to the causes of schedule overrun. Section three covers a set of four 5-point Likert-scale items on the causes of cost overrun. Section four entails a set of 13 constructs with 27 items measured on a 7-point Likert scale to determine the challenges in the implementation of a megaproject. The data from these measurements forms the Likert-scale items used in the descriptive analysis of this study. To reduce the respondents' bias, closedended questions were preferred for sections two, three and four (Akintoye \& Main, 2007: 601). The questionnaire was administered to the study sample, along with a covering letter indicating that participation in this survey was voluntary and that participants could withdraw at any point during the study.

\subsection{Analysis and interpretation of the data}

Interval Likert scales was used to measure how strongly respondents felt regarding the statements or questions in the Likert-scale constructs. Likert scales are effective where numbers can be used to quantify the results of measuring behaviours, attitudes, preferences, and even perceptions (Wegner, 2016: 11).

For the purpose of analysis of the 7-point Likert scale, the ranges relative to the MS are defined as follows: $>1.00$ to $\leq 1.86$ (strongly disagree); $>1.86$ to $\leq 2.71$ (disagree); $>2.71$ to $\leq 3.57$ (somewhat disagree); $>3.57$ to $\leq 4.44$ (neither agree nor disagree); $>4.44$ to $\leq 5.30$ (somewhat agree); $>5.30$ to $\leq 6.16$ (agree), and $>6.16$ to $\leq 7.00$ (strongly agree). For the purpose of analysis of the 5-point Likert scale, the ranges relative to the MS are defined as follows: $>1.00$ to $\leq 1.80$ (strongly disagree); $>1.80$ to $\leq 2.60$ (disagree); $>2.60$ to $\leq 3.40$ (neutral); $>3.40$ to $\leq 4.20$ (agree), and $>4.20$ to $\leq 5.00$ (strongly agree).

The Statistical Package for Social Sciences (SPSS) version 23 (Pallant, 2015) was used to process the interval scales and to analyse them, using descriptive statistics such as means, modes, and standard deviations. The mean of responses was generated, in order to analyse and rank the causes of schedule and cost overruns as well as the challenges in implementing energy megaprojects. Only the mean of the items was used to show the central tendency and to rank the factors in order of the most agreed to the least agreed. 


\subsection{Limitation of the study}

During the time of the study, Eskom, the South African public electricity utility company, was under intense public scrutiny and the subject of a number of high-profile investigations against perceived rampant graft within the organisation. The leadership instability at Eskom had occasioned a climate of mistrust to outsiders, making accessing informative sources sometimes difficult. However, those who cooperated still provided valuable information. The contractors involved would have done well to respond, but their noncooperation compelled the study to proceed without their input. It is possible that, since their client was going through a difficult time, they felt it safe for the sake of their businesses to not participate in the study, as any negative utterance could result in disadvantageous reprisals. Nevertheless, key individuals in strategic positions were engaged with, and their input proved to be crucial to the study's findings.

\section{RESULTS AND DISCUSSION}

\subsection{Respondents' profile}

Table 3 presents the profile of respondents to the questionnaire survey. The distribution shows that the majority of the respondents have between 11 and 15 years' work experience.

Table 3: Respondents' work experience

\begin{tabular}{|l|c|c|c|c|c|}
\hline $\begin{array}{l}\text { No. of years' work } \\
\text { experience) }\end{array}$ & Architect & $\begin{array}{l}\text { Quantity } \\
\text { surveyor }\end{array}$ & Engineer & $\begin{array}{l}\text { Project } \\
\text { manager }\end{array}$ & Total \\
\hline 1-5 years & & 1 & & & 1 \\
\hline 6-10 years & & & & 2 & 2 \\
\hline $11-15$ years & 1 & 2 & 3 & 2 & 8 \\
\hline $16-20$ years & 1 & & 2 & & 3 \\
\hline 21 years and above & 3 & & & & 3 \\
\hline Total respondents & 5 & 3 & 5 & 4 & 17 \\
\hline
\end{tabular}

Three architects have over 21 years' work experience, and have 16-20 years' and 11-15 years' work experience, respectively. Two quantity surveyors have 11-15 years' work experience and 1-5 years' work experience. Two engineers have 16-20 years' work experience, while three have 11-15 years' work experience. Two project managers have 6-10 years' work experience and two have 11-15 years' work experience. The greater majority of the respondents have more experience in the construction industry. 


\subsection{Ranking of the factors causing schedule overrun}

Table 4 shows the mean score, and ranks the nine factors identified from construction literature to show which factors are mostly responsible for schedule overrun in energy megaprojects.

Table 4: The causes of schedule overrun in energy megaprojects

\begin{tabular}{|c|c|c|c|c|c|c|c|c|c|c|}
\hline \multirow{3}{*}{$\begin{array}{l}\text { Factors }(N=17) \\
(1=\text { strongly } \\
\text { disagree ... } \\
7=\text { strongly agree) }\end{array}$} & \multicolumn{8}{|c|}{ Discipline } & \multirow{2}{*}{\multicolumn{2}{|c|}{ Overall }} \\
\hline & \multicolumn{2}{|c|}{ Architect } & \multicolumn{2}{|c|}{$\begin{array}{l}\text { Quantity } \\
\text { surveyor }\end{array}$} & \multicolumn{2}{|c|}{ Engineer } & \multicolumn{2}{|c|}{$\begin{array}{l}\text { Project } \\
\text { manager }\end{array}$} & & \\
\hline & $M S$ & Rank & MS & Rank & MS & Rank & $M S$ & Rank & MS & Rank \\
\hline $\begin{array}{l}\text { Incomplete } \\
\text { drawings }\end{array}$ & 3.60 & 8 & 5.00 & 3 & 4.60 & 7 & 4.00 & 6 & 4.25 & 8 \\
\hline Design changes & 4.80 & 6 & 5.33 & 2 & 5.80 & 3 & 5.75 & 3 & 5.41 & 3 \\
\hline $\begin{array}{l}\text { Slow client } \\
\text { decision-making }\end{array}$ & 6.00 & 2 & 5.33 & 2 & 6.20 & 1 & 5.25 & 5 & 5.76 & $1=$ \\
\hline $\begin{array}{l}\text { Late issue of } \\
\text { instruction }\end{array}$ & 4.40 & 7 & 4.67 & 4 & 4.80 & 6 & 5.50 & 4 & 4.82 & 6 \\
\hline $\begin{array}{l}\text { Shortage of skilled } \\
\text { labour }\end{array}$ & 6.40 & 1 & 4.00 & 5 & 6.00 & 2 & 6.00 & 2 & 5.76 & $1=$ \\
\hline $\begin{array}{l}\text { Poor planning and } \\
\text { scheduling }\end{array}$ & 5.80 & 3 & 6.00 & 1 & 5.00 & 5 & 6.25 & 1 & 5.71 & 2 \\
\hline Labour unrest & 4.80 & 6 & 4.67 & 4 & 3.40 & 8 & 5.50 & 4 & 4.53 & 7 \\
\hline $\begin{array}{l}\text { Shortage of } \\
\text { manpower }\end{array}$ & 5.60 & 4 & 4.67 & 4 & 5.00 & 5 & 5.50 & 4 & 5.24 & 5 \\
\hline $\begin{array}{l}\text { Delay in work } \\
\text { approval }\end{array}$ & 5.20 & 5 & 4.00 & 5 & 5.40 & 4 & 6.25 & 1 & 5.29 & 4 \\
\hline $\begin{array}{l}\text { Average MS } \\
\text { (composite score) }\end{array}$ & & & & & & & & & 5.22 & \\
\hline
\end{tabular}

The factors in Table 4 were ranked per discipline, and the results indicated that architects believed that the number one cause of schedule overrun is shortage of skilled labour with MS 6.40. Quantity surveyors believed that poor planning and scheduling is the number one factor causing schedule overrun with MS 6.00. The engineers ranked slow client decision-making as the number one factor causing schedule overrun with MS 6.20. Project managers ranked poor planning and scheduling as the number one factor causing schedule overrun with MS 6.25.

Shortage of skilled labour, poor planning and scheduling, and slow client decision-making were rated as the top three causes by the architects, quantity surveyors, engineers, and project managers who participated in the survey and who are also working on megaprojects in South Africa. Shortage of skilled labour, which could affect planning, design, and scheduling, may be a result of the rushed implementation of these megaprojects in South Africa. The rushed implementation does not allow adequate staffing and upskilling of key personnel. This means that the very 
foundations of the implementation process are shaky from the onset. It also cascades to other problems downstream, such as incomplete drawings, a great deal of rework, and design changes, as depicted in Table 4. This has been a very unfortunate South African trademark in the implementation of energy megaprojects.

The average mean of 5.22 demonstrates that, overall, all the factors cause schedule overrun in energy megaprojects in South Africa.

Slow client decision-making with MS 5.76 and shortage of skilled labour with MS 5.76 are ranked as the number one factors that cause schedule overrun in study area megaprojects. Poor planning and scheduling with MS 5.71, design changes with MS 5.41, and delay in work approval with MS 5.29 are ranked number two to four, respectively. The results in Table 4 show that these factors could contribute to project implementation sluggishness in South Africa. A study by Tahir et al. (2017: 3) indicated that the project teams' slow rate in making decisions is one of the causes of delay that could contribute to project implementation sluggishness. The issues identified in this instance are indicative of project management teams that are either overwhelmed or not sufficiently knowledgeable. The results appear not to show that the influence of external factors (Musa, 2012: 6) such as labour unrest and shortage of manpower is not very strong, again putting the blame on the technical capacity of the project managers/implementers.

\subsection{Ranking of the factors causing cost overrun}

Table 5 shows the mean score, and ranks the four factors identified from construction literature to show which factors are mostly responsible for cost overrun in energy megaprojects.

Table 5: The causes of cost overrun in energy megaprojects

\begin{tabular}{|c|c|c|c|c|c|c|c|c|c|c|}
\hline \multirow{3}{*}{$\begin{array}{l}\text { Factors }(N=17) \\
(1=\text { strongly disagree } \\
\ldots 5=\text { strongly agree })\end{array}$} & \multicolumn{8}{|c|}{ Discipline } & \multirow{2}{*}{\multicolumn{2}{|c|}{ Overall }} \\
\hline & \multicolumn{2}{|c|}{ Architect } & \multicolumn{2}{|c|}{$\begin{array}{l}\text { Quantity } \\
\text { surveyor }\end{array}$} & \multicolumn{2}{|c|}{ Engineer } & \multicolumn{2}{|c|}{$\begin{array}{l}\text { Project } \\
\text { manager }\end{array}$} & & \\
\hline & MS & Rank & $M S$ & Rank & MS & Rank & $M S$ & Rank & $M S$ & Rank \\
\hline $\begin{array}{l}\text { Increase in } \\
\text { material cost }\end{array}$ & 3.20 & 4 & 3.00 & 2 & 3.00 & 4 & 3.00 & 2 & 3.06 & 4 \\
\hline $\begin{array}{l}\text { Inaccurate material } \\
\text { estimate }\end{array}$ & 4.60 & 1 & 2.33 & 3 & 4.40 & 1 & 3.00 & 2 & 3.76 & 1 \\
\hline $\begin{array}{l}\text { Shortage of } \\
\text { skilled labour }\end{array}$ & 3.60 & 3 & 2.33 & 3 & 4.20 & 2 & 4.00 & 1 & 3.65 & 2 \\
\hline $\begin{array}{l}\text { Client's late } \\
\text { contract award }\end{array}$ & 4.00 & 2 & 3.67 & 1 & 3.20 & 3 & 2.50 & 3 & 3.35 & 3 \\
\hline $\begin{array}{l}\text { Average MS } \\
\text { (composite score) }\end{array}$ & & & & & & & & & 3.45 & \\
\hline
\end{tabular}


The factors in Table 5 were ranked per discipline, and the results indicated that architects believed that the number one cause of cost overrun is inaccurate material estimating, with MS 4.60. Quantity surveyors believed that client's late contract award is the number one factor causing cost overrun, with MS 3.67. The engineers ranked inaccurate material estimating number one factor causing cost overrun, with MS 4.40. Project managers ranked shortage of skilled labour as the number one factor causing cost overrun, with MS 4.00. According to the consultants who participated in this study, inaccurate material estimates, shortage of skilled labour, and the client's late contract award are regarded as the main causes of cost overrun in energy sector megaprojects in South Africa. The findings of Musa (2012: 13) show that insufficient labour skills could affect the proper estimating of materials, given the enormity and complexity of the projects. It is intriguing that there appears to be some congruence in responses from people from different disciplines. However, unlike in Malaysia (Tahir et al., 2017: 1), where there appears to be changes in laws and regulations during project execution, this does not seem to be a challenge in this instance, meaning that there is simply lack of knowledge on proper executing methods.

The average mean of 3.45 demonstrates that, overall, all the factors cause schedule overrun in energy megaprojects in South Africa.

Inaccurate material estimate, with MS 3.76, is the number one ranked factor causing cost overrun in study area megaprojects. Shortage of skilled labour, with MS 3.65, client's late contract award, with MIS 3.35 , and increase in material cost with MIS 3.06 are ranked numbers 2 to 4 , respectively. It is very instructive for other megaprojects that are heavily reliant on imported components and materials that the scheduling be done properly, in order to avoid any inefficiencies that could hamper implementation. The energy products were using highly specialised components produced by niche manufacturers who might be inundated with orders from across the globe. Thus, any misestimated order would have to wait for a long time to augment the numbers. The actual issuing of contracts is hardly surprising, as the lack of experts working for the public sector could mean that it takes time to source the expertise or that the in-house expertise is inundated with the workload.

\subsection{Ranking of challenges in the implementation of energy megaprojects}

Table 6 shows the mean score, and ranks the 27 items identified from construction literature to show the overall challenges with the implementation of energy megaprojects. From Table 6 , poor site management $(M S=6.71)$, inadequate managerial skills $(\mathrm{MS}=6.65)$, poor monitoring and control $(\mathrm{MS}=6.53)$, unstable management structure $(\mathrm{MS}=6.41)$, and lack of 
experience together with poor organisation structures $(M S=6.29)$ are the dominant challenges in South Africa.

Table 6: Challenges in the implementation of energy megaprojects

\begin{tabular}{|c|c|c|c|c|}
\hline Construct & $\begin{array}{l}\text { Items affecting the implementation of } \\
\text { megaproject }(N=17)(1=\text { strongly } \\
\text { disagree } \ldots 7=\text { strongly agree })\end{array}$ & MS & Rank & $\begin{array}{l}\text { Overall } \\
\text { rank }\end{array}$ \\
\hline \multirow{2}{*}{$\begin{array}{l}\text { Communication } \\
\text { factors }\end{array}$} & $\begin{array}{l}\text { Lack of communication between } \\
\text { contractor and client }\end{array}$ & 5.47 & 2 & 17 \\
\hline & Inefficient communication & 5.82 & 1 & 10 \\
\hline \multirow{4}{*}{ Management } & Poor site management & 6.71 & 1 & 1 \\
\hline & Inadequate managerial skills & 6.65 & 2 & 2 \\
\hline & Poor monitoring and control & 6.53 & 3 & 3 \\
\hline & Slow decision making & 6.18 & 4 & 7 \\
\hline \multirow{4}{*}{ Personnel } & $\begin{array}{l}\text { Shortage of managerial and supervisory } \\
\text { staff }\end{array}$ & 6.12 & 3 & 8 \\
\hline & Shortage of skilled labour & 6.24 & 2 & $6=$ \\
\hline & Lack of experience & 6.29 & 1 & $5=$ \\
\hline & Low motivation & 5.41 & 4 & 18 \\
\hline \multirow{2}{*}{ Organisational } & Unstable management structure & 6.41 & 1 & 4 \\
\hline & Poor organisation structure & 6.29 & 2 & $5=$ \\
\hline \multirow{4}{*}{ Planning } & Client initiated change order & 5.71 & 2 & 12 \\
\hline & Inadequate design specification & 5.82 & 1 & 10 \\
\hline & Rework & 5.71 & 2 & 12 \\
\hline & Poor labour planning & 5.59 & 3 & 14 \\
\hline Site conditions & Unforeseen ground conditions & 5.53 & & 16 \\
\hline Weather & Harsh weather conditions & 4.94 & & 20 \\
\hline \multirow{2}{*}{ Project-related } & Project complexity & 5.65 & 1 & 13 \\
\hline & Project duration & 4.94 & 2 & 20 \\
\hline \multirow{2}{*}{ Material-related } & Shortage of equipment & 5.24 & 2 & 19 \\
\hline & Poor material planning & 6.24 & 1 & $6=$ \\
\hline Other & $\begin{array}{l}\text { Slow decision-making, knowledge } \\
\text { of specifications, material ordering, } \\
\text { approved materials, increase in } \\
\text { material cost, and market unavailability }\end{array}$ & 5.57 & & 15 \\
\hline Process-related & Poor procedures & 5.76 & & 11 \\
\hline \multirow[t]{2}{*}{ Financial } & $\begin{array}{l}\text { Delayed payment to contractors/ } \\
\text { consultants }\end{array}$ & 6.24 & 1 & $6=$ \\
\hline & Poor financial planning & 6.06 & 2 & 9 \\
\hline Price-related & Price increase & 4.94 & & 20 \\
\hline $\begin{array}{l}\text { Average MS } \\
\text { (composite score) }\end{array}$ & & 5.85 & & \\
\hline
\end{tabular}

The top five challenges are management and organisational related, showing that there is not enough local management and organisational expertise in South Africa to ensure the proper planning and effective implementation 
of energy megaprojects. One essential and critical issue in successful implementation is the management and organisation of megaprojects (Söderlund et al., 2018: 9) Since these projects are critical to the economy, adequate planning for their implementation should have been carried out (Tahir et al., 2017). With MS $=6.24$, respondents agreed that shortage of skilled labour; poor material planning, and delayed payment to contractors/ consultants, which relates to personnel, material and financial issues, is challenging for the successful implementation of energy megaprojects in South Africa. It is imperative for Eskom that the majority of the top managers be skilled, well trained and stay employed for the long haul, in order to preserve institutional memory and to learn from their mistakes so that they can make well-informed decisions when required.

\section{CONCLUSION AND RECOMMENDATIONS}

This study assessed the causes of cost and schedule overruns as well as the challenges with the implementation of energy sector megaprojects in South Africa. The study identified the causes of schedule and cost overruns as well as the challenges militating against the project's implementation success.

The results show that architects, quantity surveyors, engineers, and project managers, who participated in the survey and who are also working on megaprojects in South Africa, rated shortage of skilled labour, poor planning and scheduling, and slow client decision-making as the top three causes for schedule overruns. Inaccurate material estimate, client's late contract award, shortage of skilled labour, and increase in material cost were rated the top four factors causing cost overrun in energy megaprojects.

The top five challenges in the successful implementation of energy megaprojects in South Africa were poor site management, inadequate managerial skills, poor monitoring and control, unstable management structure, poor organisation structure, and lack of experience. Most of these challenges are management and organisational related, showing that there is no adequate local management and organisational expertise in South Africa to ensure the proper planning and effective implementation of energy megaprojects.

South Africa should take the hard lessons garnered so far and accept that capacitation is needed to implement these huge critical projects. The national energy needs projections should be revised periodically, and interventions by way of new projects should never be rushed. The study has shown that, although the challenges bedevilling megaprojects are the same globally, as they are in South Africa, the South African causes of budget overflow and programme slippage are particularly preventable, 
as they appear to be underpinned by poor planning and management. The improvement of implementation performance is critical, as there are likely to be more critical megaprojects yet to be implemented. Since there are no specific solutions to mitigate the factors in existing literature, it is thus recommended that specific solutions that could mitigate the causes of cost and schedule overruns be included in future studies. The following recommendations are proposed for further studies:

- The study should investigate the effectiveness of megaprojects procurement systems in South Africa.

- The study should also investigate the level of expertise of South African construction professionals in handling complex projects with intricate interfaces.

- The study of the specific nuances of critical energy projects should be prioritised.

\section{REFERENCES}

Adugna, N. 2015. A study of causes of delay and cost overrun in office construction projects in the eThekwini Municipal Area, South Africa. s.l.: Durban University of Technology.

Akanni, P.O., Oke, A.E. \& Akpomiemie, O.A. 2014. Impact of environmental factors on building project performance in Delta State, Nigeria. HBRC Journal, 11(1), pp. 91-97. https://doi.org/10.1016/j.hbrcj.2014.02.010.

Akintoye, A. \& Main, J. 2007. Collaborative relationships in construction: The UK contractor's perception. Engineering, Construction and Architectural Management, 14(6), pp. 597-617. http://dx.doi. org/10.1108/09699980710829049.

Alaghbari, W., Kadir, M.R.A., Salim, A. \& Ernawati, B. 2007. The significant factors causing delay of building construction projects in Malaysia. Engineering, Construction and Architectural Management, 14(2), pp. 192-206. https://doi.org/10.1108/09699980710731308.

Aljohani, A., Ahiaga-Dagbui, D. \& Moore, D. 2017. Construction projects cost overrun: What does the literature tell us? International Journal of Innovation, Management and Technology, 8(2), pp. 137-143. https://doi. org/10.18178/ijimt.2017.8.2.717.

Alvi, M.H. 2016. A manual for selecting sampling techniques in research. University of Karachi, Iqra University, Karachi, Sindh, Pakistan.

ARUP, 2012. Multi-Products Pipeline. South Africa's largest pipeline project, valued at US\$2bn. [Online]. Available at: <https://www.arup.com/projects/ multi-products-pipeline> [Accessed: 17 October 2017]. 
Ballard, R. \& Rubin, M. 2017. A 'Marshall' plan for human settlements: How megaprojects became South Africa's housing policy. Transformation: Critical Perspectives on Southern Africa, 95(1), pp. 1-31. https://doi.org/10.1353/ $\operatorname{trn} .2017 .0020$.

Barradas, S. 2017. Durban port upgrade and expansion project, South Africa. [Online]. Available at: <http://www.engineeringnews.co.za/article/durbanport-upgrade-and-expansion-project-south-africa-2017-01-20> [Accessed: 3 March 2018].

Barradas, S. 2019. Durban port upgrade and expansion project, South Africa. [Online]. Available at: <http://researchchannel.co.za/login.php?url=/article/ durban-port-upgrade-and-expansion-project-south-africa-2019-05-31> [Accessed: 20 March 2020].

Bishop, P. \& Herron, R. 2015. Use and misuse of the Likert item responses and other ordinal measures. International Journal of Exercise Science, 8(3), pp. 297-302.

Brookes, N.J. \& Locatelli, G., 2015. Power plants as megaprojects: Using empirics to shape policy, planning, and construction management. Utilities Policy, 36, pp. 57-66. https://doi.org/10.1016/j.jup.2015.09.005.

Brown, T.A. 2015. Confirmatory factor analysis for applied research. $2^{\text {nd }}$ edition. New York, NY: The Guilford Press.

Burkhardt, P. \& Cohen, M. 2019. How Medupi and Kusile are sinking South Africa. [Online]. Available at: <https://www.fin24.com/Budget/how-medupi-and-kusileare-sinking-south-africa-20191009> [Accessed: 31 December 2019].

Burns, N. \& Groves, K. 1993. The practice of nursing research conduct, critique and utilization. $2^{\text {nd }}$ edition. Philadelphia, PA: WB Saunders Company.

Callegari, C., Szklo, A. \& Schaeffer, R. 2018. Cost overruns and delays in energy megaprojects: How big is big enough? Energy Policy, 114(C), pp. 211-220. https://doi.org/10.1016/j.enpol.2017.11.059.

CISA, 2019. Critical Infrastructure Security and Resilience. [Online]. Available at: <https://www.hsdl.org> [Accessed: 1 January 2019].

Cox, B.G. 2011. Encyclopedia of survey research methods - Sage research methods. [Online]. Available at: <https://methods.sagepub.com/base/down load/ReferenceEntry/encyclopedia-of-survey-research-methods/n571. xml> [Accessed: 5 January 2020].

Creswell, J.W. 2014. Research design: Qualitative, quantitative and mixed methods approaches. $4^{\text {th }}$ edition. Thousand Oaks, CA: Sage. 
Critical5. 2015. Role of critical infrastructure in national prosperity. [Online]. Available at: <https://www.publicsafety.gc.ca/cnt/rsrcs/pblctns/2016-rlcrtclnfrstrctr-ntn|prsprty/2016-rl-crtclnfrstrctr-ntnlprsprty-en.pdf> [Accessed: 1 January 2020].

Deloitte. 2014. Deloitte on Africa. African Construction Trends Report. [Online]. Available at: <https://www2.deloitte.com/content/dam/Deloitte/za/ Documents/manufacturing/za_africa_construction_trends_2015_10032015. pdf.> [Accessed: 5 March 2018].

Department of Homeland Security. 2019. Critical infrastructure sectors. [Online]. Available at: <https://www.dhs.gov/cisa/critical-infrastructuresectors> [Accessed: 1 January 2020].

Dupont, V. 2013. Which place for the homeless in Delhi? Scrutiny of a mobilisation campaign in the 2010 Commonwealth Games context. South Asia Multidisciplinary Academic Journal, Online issue 8. https://doi. org/10.4000/samaj.3662.

Eskom. 2014. Fact sheet-Medupi power station project. [Online]. Available at: <http://www.eskom.co.za/Whatweredoing/NewBuild/MedupiPowerStation/ Pages/Medupi_Power_Station_Project.aspx> [Accessed: 5 January 2020].

Eskom. 2019. Kusile power station project. [Online]. Available at: <http:// www.eskom.co.za/Whatweredoing/NewBuild/Pages/Kusile_Power_ Station.aspx> [Accessed: 30 September 2019].

Famiyeh, S., Amoatey, C.T., Adaku, E. \& Agbenohevi, C.S. 2017. Major causes of construction time and cost overruns: Acase of selected educational sector projects in Ghana. Journal of Engineering, Design and Technology, 15(2), pp. 181-198. https://doi.org/10.1108/JEDT-11-2015-0075.

Flyvbjerg, B. 2014. What you should know about megaprojects and why: An overview. Project Management Journal, 45(2), pp. 6-19. https://doi. org/10.1002/pmj.21409.

Flyvbjerg, B., Bruzelius, N. \& Rothengatter, W. 2003. Megaprojects and risk: An anatomy of ambition. New York: Cambridge University Press. https://doi. org/10.1017/CBO9781107050891.

Globe Newswire. 2019. Power generation ponstruction Projects: Global insights (2019-2024) by country, stage, value and type of power generation construction. [Online]. Available at: <https://www.globenewswire.com/ news-release/2019/06/21/1872510/0/en/Power-Generation-ConstructionProjects-Global-Insights-2019-2024-by-Country-Stage-Value-and-Type-ofPower-Generation-Construction.html> [Accessed: 31 December 2019]. 
Gosling, M. 2019. Eskom and the multi-billion rand mega projects that could have saved South Africa. [Online]. Available at: <https://www.fin24.com/ Economy/eskom-and-the-multi-billion-rand-mega-projects-that-couldhave-saved-sa-20190213> [Accessed: 1 January 2020].

Gray, R. 2017. Getting power to people where and when it's needed could rewrite the geopolitical rulebook. [Online]. Available at: <https://www. bbc.com/future/article/20170313-the-biggest-energy-challenges-facinghumanity> [Accessed: 3 December 2019].

Groenewald,Y. 2017. Durban/Joburg fuel pipeline opens after years of delays, spiralling cost. [Online]. Available at: <https://m.fin24.com/Companies/ Industrial/durbanjoburg-fuel-pipeline-opens-after-years-of-delaysspiralling-costs-20171006> [Accessed: 20 March 2020].

Gualini, E. \& Majoor, S. 2007. Innovative practices in large urban development projects: Conflicting frames in the quest for "new urbanity". Planning Theory \& Practice, 8(3), pp. 297-318. https://doi.org/10.1080/14649350701514637.

Harrison, P. \& Todes, A. 2017. Satellite settlement on the spatial periphery: Lessons from international and Gauteng experience. Transformation: Critical Perspectives on Southern Africa, 95(1), pp. 32-62. https://doi. org/10.1353/trn.2017.0021.

IEA. 2014. World Energy Investment Outlook 2014. [Online]. Available at: $<$ http://www.iea.org/publications/freepublications/publication/weio2014. pdf> [Accessed: 31 December 2019].

Krejcie, R.V. \& Morgan, D.W. 1970. Determining sample size for research activities. Educational and Psychological Measurement, vol. 30, pp. 607-610. https://doi.org/10.1177/001316447003000308.

Locatelli, G., Palerma, E. \& Mancini, M. 2015. Assessing the economics of large energy storage plants with an optimisation methodology. Energy, 83, pp. 15-28. https://doi.org/10.1016/j.energy.2015.01.050.

Ma, H., Zeng, S., Lin, H., Chen, H. \& Shi, J.J. 2017. The societal governance of megaproject social responsibility. International Journal of Project Management, 35(7), pp. 1365-1377. https://doi.org/10.1016/j. ijproman.2017.01.012.

Mail and Guardian. 2019. Eskom's Medupi and Kusile to cost R36bn to complete, will notbehalted-Mabuza. [Online].Availableat:<https://mg.co.za/ article/2019-04-04-eskoms-medupi-and-kusile-to-cost-r36bn-to-completewill-not-be-halted-mabuza/> [Accessed: 5 January 2020].

Maïzi, N. \& Assoumou, E. 2014. Future prospects for nuclear power in France. Applied Energy, 136, pp. 849-859. https://doi.org/10.1016/j. apenergy.2014.03.056. 
Moyo, A. \& Crafford, G. 2010. The impact of hyperinflation on the Zimbabwean construction industry. Acta Structilia, 17(2), pp. 53-83.

Mukuka, M., Aigbavboa, C. \& Thwala, W. 2015. Effects of construction projects schedule overruns: A case of the Gauteng Province, South Africa. Procedia Manufacturing, 2, pp. 1690-1695. https://doi.org/10.1016/j. promfg.2015.07.989.

Musa, I. 2012. The causes and effect of delay in construction industry project. Thesis (BSc). Pahang: University Malaysia.

Mybroadband. 2019. Here is the true cost of Eskom's Medupi and Kusile power stations. [Online]. Available at: <https://mybroadband.co.za/news/ energy/318251-here-is-the-true-cost-of-eskoms-medupi-and-kusile-powerstations.html> [Accessed: 5 January 2020].

Netemeyer, R.G., Bearden, W.O. \& Sharma, S. 2003. Scaling procedures: Issues and applications. London, United Kingdom: Sage Publications. https://doi.org/10.4135/9781412985772.

Olatunji, A. 2010. Influence on construction project delivery time. Thesis $(\mathrm{PhD})$. Nelson Mandela Metropolitan University, Port Elizabeth, South Africa.

Padayachee, V. 2013. Introducing varieties of capitalism into the South African debate: Uses and limits. Transformation: Critical Perspectives on Southern Africa, 81(1), pp. 5-32. https://doi.org/10.1353/trn.2013.0017.

Pallant, J. 2015. SPSS survival manual. Berkshire: Open University Press.

Phaahla, E. 2015. Medupi timeline: Costs, delays spiralling - no completion in sight. [Online]. Available at: <https://www.fin24.com/BizNews/Medupitimeline-Costs-delays-spiralling-no-completion-in-sight-20150806> [Accessed: 21 February 2017].

Ramabodu, M.S. \& Vester, J. 2013. Factors that influenced cost overruns in South African public sector mega-projects. International Journal of Project Management, 5(12), pp. 48-56. https://doi.org/10.1504/ IJPOM.2013.053153.

Shrestha, P.P., Burns, L.A. \& Shields, D.R. 2013. Magnitude of construction cost and schedule overruns in public work projects. Journal of Construction Engineering, 2013, p. 9. https://doi.org/10.1155/2013/935978.

Siemiatycki, M. 2015. Cost overruns on infrastructure projects: Patterns, causes, and cures. IMFG Perspectives Papers, 11, pp. 1-10.

Siemiatycki, M. 2017. Cycles in megaproject development. In: Flyvbjerg, B. (Ed.). The Oxford handbook of megaproject management. Oxford, UK: Oxford University Press, pp. 39-60. https://doi.org/10.1093/ oxfordhb/9780198732242.013.3. 
Sims, R.E., Rogner, H.-H. \& Gregory, K. 2003. Carbon emission and mitigation cost comparisons between fossil fuel, nuclear and renewable energy resources for electricity generation. Energy Policy, 31, pp. 1315-1326. https://doi.org/10.1016/S0301-4215(02)00192-1.

Söderlund, J., Sankaran, S. \& Biesenthal, C. 2018. The past and present of megaprojects. Project Management Journal, 48(6), pp. 5-16. https://doi. org/10.1177/875697281704800602.

Subramani, T., Sruthi, P.S. \& Kavitha, M. 2014. Causes of cost overrun in construction. IOSR Journal of Engineering, 4(6), pp. 1-7. https://doi. org/10.9790/3021-04640107.

Sutherland, C., Sim, V. \& Scott, D. 2015. Contested discourses of mixeduse megaproject: Cornubia, Durban. Habitat International, 45(3), pp. 185195. https://doi.org/10.1016/j.habitatint.2014.06.009.

Tahir, M.M., Haron, N.A., Alias, A.H. \& Diugwu, I.A. 2017. Causes of delay and cost overrun in Malaysian construction industry. In: Pradhan, B. (Ed.). Proceedings of the $1^{\text {st }}$ Global Civil Engineering Conference, GCEC 2017, 25-28 July, Kuala Lumpur, Malaysia, pp. 47-57. https://doi. org/10.1007/978-981-10-8016-6_5.

Trueman, C.N. 2019. Structured questionnaires. [Online]. Available at: <https://www.historylearningsite.co.uk/sociology/research-methods-insociology/structured-questionnaires/> [Accessed: 5 January 2020].

Vidalis, S.M. \& Najafi, F.T. 2002. Cost and time overruns in highway construction. In: Proceedings of the Canadian Society for Civil Engineering - 30 ${ }^{\text {th }}$ Annual Conference, 5-8 June, Montreal, Canada, 5, pp. 2388-2397.

Wegner, T. 2016. Applied business statistics methods and excel-based applications solutions manual. $4^{\text {th }}$ edition. Cape Town: Juta.

Wolpe, H. 1975. The theory of internal colonization: The South African case. Institute of Commonwealth Studies, 18, pp. 105-120.

Yelland, C. 2019. The crisis at Kusile and Medupi continues .... [Online]. Available at: <https://www.moneyweb.co.za/news/south-africa/the-crisisat-kusile-and-medupi-continues/> [Accessed: 5 January 2020]. 